\title{
Genetic parameters for Icelandic dairy cows using a random regression test-day model
}

\author{
Jón H. EiríksSON ${ }^{1}$, ÁgúSt SigurdSSON ${ }^{1}$, GUdMUNdUR JóHANNESSON² \& \\ EMMA EYTHÓRSDÓTTIR ${ }^{1}$ \\ 1 Agricultural University of Iceland, Hvanneyri, 311 Borgarnes, Iceland \\ 2 Icelandic Agricultural Advisory Centre \\ E-mail:nonnikotinu@gmail.com; agust@kirkjubaer.is; mundi@rml.is; emma@lbhi.is
}

\begin{abstract}
A total of 480,495 test-day yield records of 33,052 cows were used to estimate the genetic parameters for daily milk yield (MY), fat yield (FY), protein yield (PY) and somatic cell score (SCS) of Icelandic dairy cows in the first three lactations with a random regression model.

Heritability of all traits was lowest in early lactation in all lactations and highest in mid- or late lactation. Heritability of lactation yields for the first lactation was $0.43,0.39$ and 0.41 for MY, FY and PY, respectively, but was estimated as lower when using a lactation model. Heritability of SCS in the first lactation was 0.23 using the random regression model but 0.15 using the lactation model. Heritability of persistency of lactation MY, FY and PY were 0.14-0.24 in all lactations and genetic correlations to the whole lactation SCS were -0.08 to -0.13 . Heritability of yields had increased from previous estimates for the breed. Genetic variation of persistency in the population makes change of the lactation curve possible through selection.
\end{abstract}

Keywords: Daily yield, lactation, persistency, somatic cell count, test-day.

\section{YFIRLIT}

Erfðastuðlar fyrir islenskar mjólkurkýr með moelidagalikani

Alls voru 480.495 mælingar á daglegri nyt 33.052 íslenskra kúa notaðar til að meta erfðastuðla fyrir mjólkurmagn, fitumagn, próteinmagn og frumutölu á fyrstu premur mjaltaskeiðum með slembiaðhvarfslíkani.

Arfgengi allra eiginleika var lægst í upphafi mjaltaskeiðs en hæst um eða eftir mitt mjaltaskeið. Arfgengi mjaltaskeiðsafurða á fyrsta mjaltaskeiði var $0,43,0,39$ and 0,41 fyrir mjólk, fitu og prótein í pessari röð, samkvæmt slembiaðhvarfslíkaninu en lægri miðað við mjaltaskeiðslíkan. Arfgengi frumutölu á fyrsta mjaltaskeiði var 0,23 samkvæmt slembiaðhvarfslíkaninu en 0,15 samkvæmt mjaltaskeiðslíkani. Arfgengi mjólkurbols var á bilinu 0,14 til 0,24 fyrir mjólk, prótein og fitu á öllu mjaltaskeiðum og hafði erfðafylgni á bilinu $-0,08$ til $-0,13$ við frumutölu á sama mjaltaskeiði. Arfgengi afurðaeiginleika var metið hærra í pessari rannsókn en í eldri rannsóknum á stofninum. Erfðabreytileiki á mjólkurúthaldi í stofninum gerir kleift að breyta lögun mjaltakúrfunnar fyrir íslenskar kýr með úrvali.

\section{INTRODUCTION}

Exchange of genetic material between Icelandic dairy cattle and cattle breeds from other countries is believed to have been negligible for the last few centuries, making the Icelandic dairy cow population an isolated breed (Adalsteinsson 1981). The population consists of 26,341 dairy cows (Hagstofa Íslands 2017). Genetic evaluation for the breed is currently based on a 
lactation-yield animal model for the milk yield (MY) of the first three lactations, fat yield (FY), protein yield (PY), protein percentage and fat percentage. Sigurdsson (1993) estimated genetic parameters for production traits of Icelandic cows for the first three lactations. He found the 305-day lactation MY, FY and PY to have low heritability. Heritability was highest 0.17 for first lactation MY and FY, but lowest 0.08 for third lactation FY. Later publications (Sigurdsson \& Jonmundsson 2011) reported slightly higher heritability of first lactation, $0.24,0.20$ and 0.20 for MY, FY and PY, respectively. Jónmundsson et al. (1977) estimated the heritability of peak daily MY to be 0.10 . Genetic parameters of daily yields throughout lactation have not been studied for the Icelandic breed before.

Somatic cell count has been included in genetic evaluations since 1997 as somatic cell score $(\mathrm{SCS})=\log _{2}(\mathrm{SCC} / 100,000)+3$ where SCC is the somatic cell count (Sigurðsson 1997). Jónsson et al. (1994) estimated the heritability of lactation average $\log$ SCC to be $0.08-0.18$ for the first four lactations.

Test-day (TD) models use records of daily yield straight into the genetic analysis. This gives the opportunity to account for the effects of a short term production environment, affecting only production on one or a few days (Dzomba et al. 2010). Random regression (RR) models for genetic evaluation of MYs were introduced by Schaeffer \& Dekkers (1994). Genetic evaluations with RR models estimate breeding values as parameters describing the deviation of the cow's lactation curve from the average curve, allowing for different breeding values for different parts of the lactation period (Schaeffer \& Dekkers 1994). Meyer \& Hill (1997) showed that covariance functions are equivalent to RR. Covariance functions are a method to study the variance of longitudinal data that changes with a continuous variable, e.g. size with age or milk yield with days from calving (Kirkpatrick et al. 1994). In theory, yield at each day can be viewed as a separate trait. However, applying a multitrait model on daily yields would result in very large (co) variance matrices. Fitting covariance functions to these (co)variance matrices allows for the (co)variance to change continuously and be described with fewer parameters (Kirkpatrick et al. 1994). Covariance functions are the genetic parameters for RR models and can be estimated directly from data with for example REML methods (Mayer \& Hill 1997).

The first RR models modelled the effect of the permanent environment (PE) of each cow to be constant throughout lactation, which resulted in overestimated heritability, especially near the beginning and end of the lactation (Kettunen et al. 2000). Later models usually fit a covariance function for the PE part (Jakobsen et al. 2002). Models also vary in the way residual variance is modelled, either as constant (e.g. Jakobsen et al. 2002) or more complete models with different variance at different times of the lactation (e.g. Lidauer et al. 2015).

RR models make better use of incomplete lactations and lactations in progress, offer the possibility to examine differences in the shape of the lactation curve and the persistency of lactation (Dzomba et al. 2010). After first being implemented in Canada in 1999 (Schaeffer et al. 2000) RR models have become the standard for national and even multinational genetic evaluation of dairy cattle (e.g. Lidauer et al. 2015).

The objective of this study was to get good estimates of genetic parameters for a random regression TD model for daily MY, PY, FY, and SCS for Icelandic dairy cows. Parameters for a lactation model were estimated for comparison. Genetic variation for persistency of lactation was also investigated.

\section{MATERIALS AND METHODS Data}

A total of 4.4 million monthly MY TD records from the first three parities of Icelandic dairy cows from the years 1995 to 2015 were available for this study from the database of the Farmers Association of Iceland. Milk samples for measuring protein and fat content and somatic cell count were collected 8 times per year. However, since 2004 farmers were allowed to collect samples more frequently, and monthly 
records were available from many herds from 2004 to 2015. MY records were not utilized if a milk sample was missing for that month. For the parameter estimates records were included from cows born in 1993 and later, with calving age 540-1350, 840-1800 and 1140-2250 days for first three lactations, respectively, days in milk from 5 to 305 , daily MY from 1 to $55 \mathrm{~kg}$, daily FY from 0.1 to $2.5 \mathrm{~kg}$, daily PY from 0.1 to $1.8 \mathrm{~kg}$, and somatic cell count from 1,000 to $10,000,000 \mathrm{in} \mathrm{ml} \mathrm{milk.}$

In the case of two records from the same day in the dataset, the average of the two was used. For records of a lactation of a cow to be included there had to be at least 6 records from that lactation and from all previous lactations. Instances where more than 11 records for the same cow were found within 305 days from calving were considered erroneous and removed. Records from herds with less than 500 records in total were also excluded. The number of records, means and standard deviations for the dataset are presented in Table 1. Because of the increased frequency of milk component measurements and improved recording during the study period, the number of records in the dataset is higher in the later years than in the first years studied. There were 118,120 records in the final dataset from the years 1995-2005 (11 years), while 362,375 records dated from 2006-2015 (10 years). SCS was calculated as $\mathrm{SCS}=\log _{2}(\mathrm{SCC} / 100.000)+3$ where SCC is the somatic cell count in ml milk.

The pedigree information came from the database of the Farmers Association of Iceland. The pedigree was pruned so the final pedigree file only included all animals with records and their known ancestors up to 12 generations back. Unknown parents were assigned to 8 phantom parent groups based on estimated year of birth of unknown parents, assuming a 5-year generation interval. Parents with a recorded birth year less than one year or more than 30 years earlier than a birth year of the offspring were considered erroneous and disregarded. The final pedigree file included 76,898 animals.

Herd-year groups were formed with a minimum of 30 records; if records in a year

Table 1. Number of records (N), number of cows with records, number of herd-year groups (HY), mean and standard deviations (SD) of test-day yields in the dataset used for parameter estimation.

\begin{tabular}{lrrrrrr}
\hline Trait & Lactation & \multicolumn{1}{c}{ N } & Cows & HY & Mean & SD \\
\hline \multirow{2}{*}{ Milk yield, kg } & 1 & 251294 & 33052 & 4382 & 15.5 & 4.9 \\
& 2 & 151126 & 19061 & 2896 & 19.3 & 6.6 \\
& 3 & 78075 & 9785 & 1558 & 20.4 & 7.1 \\
& 1 & 251294 & 33052 & 4382 & 0.52 & 0.15 \\
Fat yield, kg & 2 & 151126 & 19061 & 2896 & 0.64 & 0.20 \\
& 3 & 78075 & 9785 & 1558 & 0.69 & 0.21 \\
& & & & & & \\
Protein yield, & 1 & 251294 & 33052 & 4382 & 0.22 & 0.06 \\
kg & 2 & 151126 & 19061 & 2896 & 0.30 & 0.08 \\
& 3 & 78075 & 9785 & 1558 & 0.33 & 0.09 \\
& & & & & & \\
Somatic cell & 1 & 251294 & 33052 & 4382 & 2.9 & 1.6 \\
score* & 2 & 151126 & 19061 & 2896 & 3.2 & 1.6 \\
& 3 & 78075 & 9785 & 1558 & 3.4 & 1.6 \\
\hline
\end{tabular}

* $\log _{2}(\mathrm{SCC} / 100.000)+3$ where SCC is somatic cell count in ml milk 
were fewer, the records from two years were combined in one group. The number of groups is presented in Table 1. Herd-test-day groups were formed in a similar manner with a minimum of 2 records. Herd-test-day groups numbered 37,529 .

\section{Parameter estimation for TD model}

Models with Legendre polynomials (LP) of the order of three or four for additive genetic and the order four or five for PE effects were compared for first lactation SCS and PY in a small scale preliminary study. For simplification the intercept used was always 1.00 instead of 0.707 as there would be for full LP. Models with either six residual variance classes for different days in milk or assuming homogeneous residual variance were also compared. The model with order four LP for additive genetic regression, order five LP for PE and homogeneous residual variance had the lowest deviance information criterion for both PY and SCS and was used in the analysis.

The model was:

$$
\begin{aligned}
y_{t l d: j k m n o q}= & C A_{t l: j}+C M_{t l: k}+\sum_{i=0}^{4} H Y_{t l: i m}\left(c_{i}(d)\right)+H T D_{t l: n} \\
& +\sum_{i=0}^{3} a_{t l: o}\left(c_{i}(d)\right)+\sum_{i=0}^{4} p_{t l: o}\left(c_{i}(d)\right)+e_{t l d: j k m n o q}
\end{aligned}
$$

where $y_{t d d: j k m n o q}$ was the $q^{\text {th }}$ measurement of trait $t$ in lactation $l$ on day in milk $d$ on animal $o$ in calving age class $j$, last calving in month $k$, herd-year $m$ and at herd-test-day $n ; C A_{t l: j}$ was the effect of the $j^{\text {th }} 30$ day calving age period; $C M_{t l: k}$ was the effect of the $k^{\text {th }}$ calving month; $H Y_{\text {tl:im }}$ was the fixed regression coefficient on $c_{i}(d)$ within herd-year group $m ; c_{0}(d)$ was 1 ; $c_{1}(d), c_{2}(d), c_{3}(d), c_{4}(d)$ were the second, third, fourth and fifth LPs, respectively, normalized on day in milk from 5 to 305 ; $\mathrm{HTD}_{\text {tl:n }}$ was the random effect of herd-test-day $n$ with variance $\operatorname{var}(H T D)=\boldsymbol{I} \otimes \boldsymbol{D} ; a_{t: o}$ was the random additive genetic regression coefficient of animal $o$ with variance $\operatorname{var}(a)=\boldsymbol{A} \otimes \boldsymbol{G} ; p_{t:: o}$ was the random PE regression coefficient of animal $o$ with variance $\operatorname{var}(p)=\boldsymbol{I} \otimes \boldsymbol{P}$, and $e_{t l d j k m n o q}$ was the random residual with variance $\operatorname{var}(e)=\boldsymbol{I} \otimes \boldsymbol{R}$.

Genetic parameters were estimated using MCMC and the Gibbs-sampling procedure of the GIBBS3F90 program (Mizstal et al. 2016). To make the computation manageable with the available resources the evaluation was split up and six chains were run, each including two traits and three lactations for each. Priors with a minimum degree of belief were based on combined REML estimates from small evaluations of parts of the (co)variances. Results from the first 8000 rounds of the total of 118,000 rounds were disregarded as burn-in. Length of burn-in was based on visual inspection of the chain. The posterior means of every $20^{\text {th }}$ sample thereafter were used as final estimates.

In order to get one estimate for the (co) variance components that were estimated three times, the average components for each day in milk were calculated and the covariance functions for genetic and PE variance refitted on the average (co)variance matrix.

\section{Lactation yields}

The lactation yields were calculated with the same data as for the TD model. Each TD yield record was multiplied by the number of days that were closer to this TD than any other within 5 to 305 days from calving. The yield was corrected for days to the first record in the lactation. The lactation MY, FY, PY and SCS were thus:

$$
L_{a t}=\sum_{i=1}^{n} Y_{i a t} P_{i a t}
$$

where $L_{a t}$ was the lactation yield of animal $a$ for trait $t, Y_{\text {iat }}$ was the $i^{\text {th }}$ measurement of trait $t$ on animal $a$, and $P$ was calculated as

$$
\begin{gathered}
P_{i=1}=d_{i}-5+\frac{\left(d_{i+1}-d_{i}\right)}{2}-C_{d t} \\
P_{i=2 \ldots n-1}=\frac{\left(d_{i+1}-d_{i}\right)}{2}+\frac{\left(d_{i}-d_{i-1}\right)}{2} \\
P_{i=n}=305-d_{i}+\frac{\left(d_{i}-d_{i-1}\right)}{2}-G_{d t}
\end{gathered}
$$

where $C_{d t}$ is a coefficient to correct for days 
from the beginning of lactation to the first yield recorded, the same coefficient for every 5-day period, and $G_{d t}$ corrects for days from the last record to day 305 , also in 5 day periods;

$$
\begin{gathered}
C_{d t}=\frac{\sum_{j=2}^{d / 5} 5 \bar{Y}_{5 j}-\bar{Y}_{d}(d-5)}{\bar{Y}_{d}} \\
G_{d t}=\frac{\sum_{j=(305-d) / 5}^{d / 5} 5 \bar{Y}_{5 j}-\bar{Y}_{d}(305-d)}{\bar{Y}_{d}}
\end{gathered}
$$

and

$$
\bar{Y}_{d t}=\beta_{0 t}+\beta_{1 t} d+\beta_{2 t} d^{2}+\beta_{3 t} e^{-0.05 d}
$$

where $\beta_{i t}$ was estimated with regression on days 5 to 100 for the $C_{d t}$ part and 150 to 305 for the $G_{d t}$ part. Only significant $\beta_{i t}$ were included. For the rare incidents where the first or last record was between days 100 and 150, regression on the whole lactation was used.

\section{Parameter estimation for lactation yields}

Genetic parameters for lactation yields were estimated with a multitrait model including MY, FY, PY and SCS, and each of the first three parities treated as correlated traits. The model was

$y_{t l: j k m n}=C A_{t l: j}+C M_{t l: k}+H Y_{t l: m}+a_{t l: n}+e_{t l: j k m n}$

where $y_{t l: j k m n}$ was the measurement of trait $t$ in lactation $l$ on animal $n$ in calving age class $j$, last calving in month $k$, herd-year $m$; $C A_{t j}$ was the fixed effect of the $j^{\text {th }} 30$ month calving age period; $C M_{t l: k}$ was the fixed effect of calving month $k, H Y_{t l: m}$ was the fixed effect of the $m$ th herd-year group, $a_{t: n}$ was the random additive genetic effect of animal $n$ with variance $\operatorname{var}(a)=\boldsymbol{A} \otimes \boldsymbol{G}$, and $e_{t l: j k m n}$ was the random residual with variance $\operatorname{var}(e)=\boldsymbol{I} \otimes \boldsymbol{R}$.

REML methods based on EM algorithm were applied using the REMLF90 program (Misztal et al. 2016). Convergence criteria were $10^{-7}$.

\section{Persistency}

The coefficient for the linear term of the LP was investigated as a measure of persistency of lactation (Jamrozik et al. 2002). Heritability and genetic correlation with lactation yields were estimated for that trait. Correlations of these measures for MY, FY and PY to whole lactation SCS were also calculated.

\section{RESULTS}

Genetic variance of MY, PY, FY and SCS at days in milk 5-305, estimated with different traits as correlated traits, are presented in Figure 1. The three estimates gave the same results for the first lactation but for the later lactations some differences were evident. The variance of MY, SCS and PY in the first lactation did not vary greatly with days in milk but for FY the variance was $0.01 \mathrm{~kg}^{2}$ in the beginning of the lactation, and about $0.005 \mathrm{~kg}^{2}$ in later parts of the lactation. For later lactations the genetic variance of all traits was highest in the beginning, more so for the third lactation than the second. Estimates of PE variance were higher than for the genetic part (Figure 2).

The estimate of PE variance for FY was lower near the end of lactation when SCS was a correlated trait in the analysis than with MY or PY as correlated traits. For the other traits all estimates were identical. All traits in all lactations had the highest PE variance at the beginning of the lactation. The peak variance of FY in the third lactation was $0.12 \mathrm{~kg}^{2}$ in day 5 compared to $0.008 \mathrm{~kg}^{2}$ around day 200 .

Herd-test-day variance explained the highest proportion of phenotypic variance at day 100 of lactation for FY, 8\% or higher in all lactations. For MY herd-test-day variance explained $4.3-4.5 \%$ of the phenotypic variance and for PY this proportion was $6.1-6.4 \%$. Herd-testday variance only accounted for $3.3 \%$ of the phenotypic variance of SCS in day 100 of the first lactation but $4.1 \%$ and $4.7 \%$ for the second and third lactations.

Heritability of daily yields is presented in Figure 3. For the yield traits the heritability was highest in mid-lactation in all lactations, but at the end of lactation for SCS. Heritability of daily MY was highest (0.36) around day 140 in the first lactation but lowest (0.19) at the beginning of the second lactation. Heritability of daily FY 
was highest (0.24) around day 200 of the third lactation but lowest $(0.12)$ at the beginning of the second lactation. Heritability of daily PY was highest (0.32) around day 130 of the first lactation but lowest $(0.14)$ at the beginning of the second lactation. Heritability of SCS was highest (0.24) at the end of the third lactation but lowest $(0.10)$ at the beginning of the first lactation. Genetic correlations between daily yields within lactations were in general positive, high for days with short intervals between them but low or moderate between different ends of the

Figure 1. Additive genetic variance $\left(\sigma_{\mathrm{a}}^{2}\right)$ of daily milk yield (MY), fat yield (FY), protein yield (PY), and somatic cell score (SCS) on days in milk (DIM) 5-305 in lactations 1(L1), lactation 2(L2) and lactation 3(L3), estimated with MY (whole line), FY (broken line), PY (dot-line-dot) and SCS (dots) as a correlated trait.
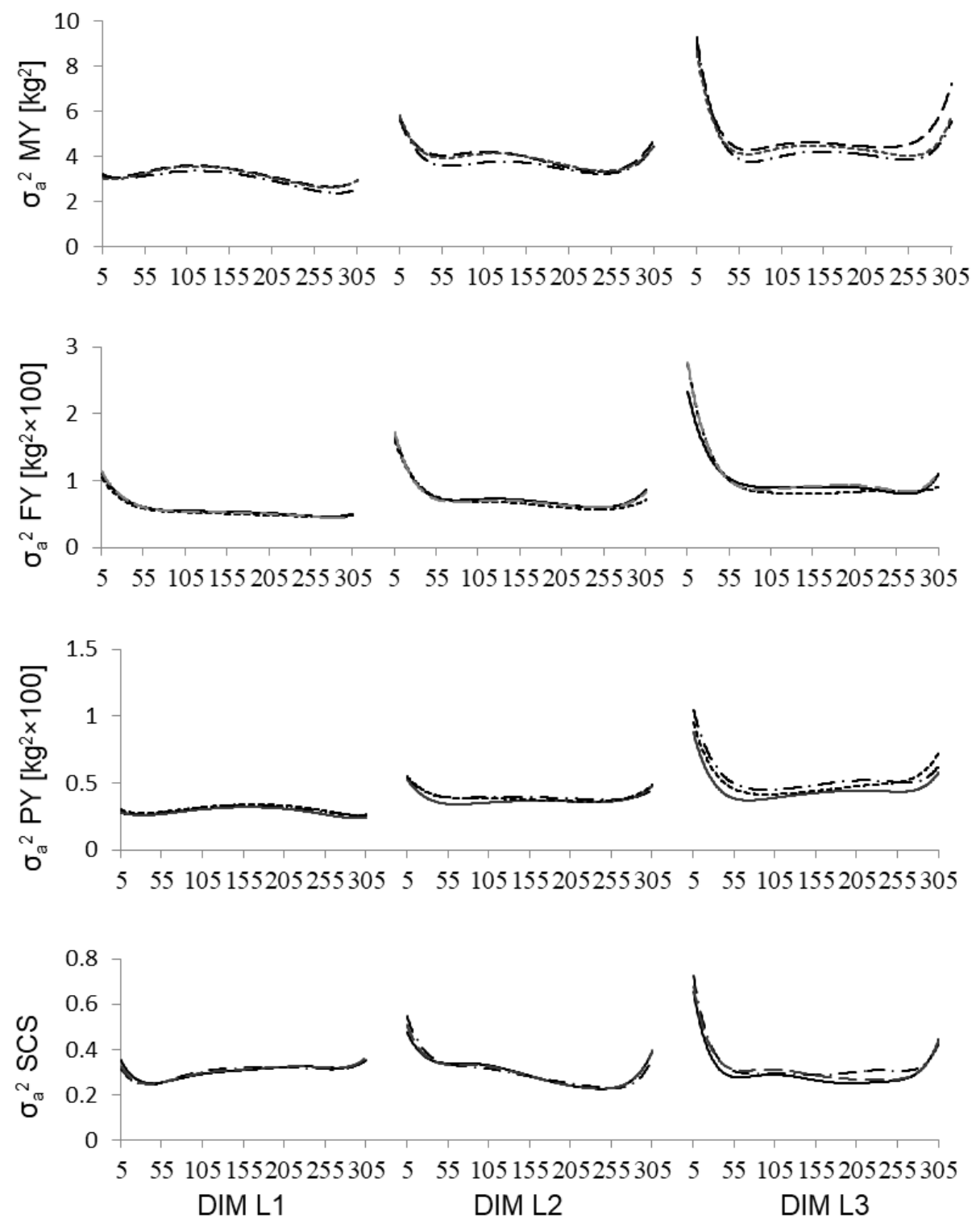
lactation (Table 4). Genetic correlation between TD yield traits was in general positive, from low to high (data not shown). Daily SCS had both negative and positive genetic correlations to the yield traits, in general lower (more negative) later in lactation and in later lactations.
The lactation model heritability and correlations between traits and lactations based on the RR model are presented in Table 2. Heritability of first lactation yields was highest, $0.43,0.39$ and 0.41 for MY, FY and PY, respectively. Heritability of yields in later

Figure 2. Permanent environment variance $\left(\sigma_{\mathrm{pe}}{ }^{2}\right)$ of daily milk yield (MY), fat yield (FY), protein yield (PY), and somatic cell score (SCS) on days in milk (DIM) 5-305 in lactations 1(L1), lactation 2(L2) and lactation 3(L3), estimated with MY (whole line), FY (broken line), PY (dot-line-dot) and SCS (dots) as a correlated trait.
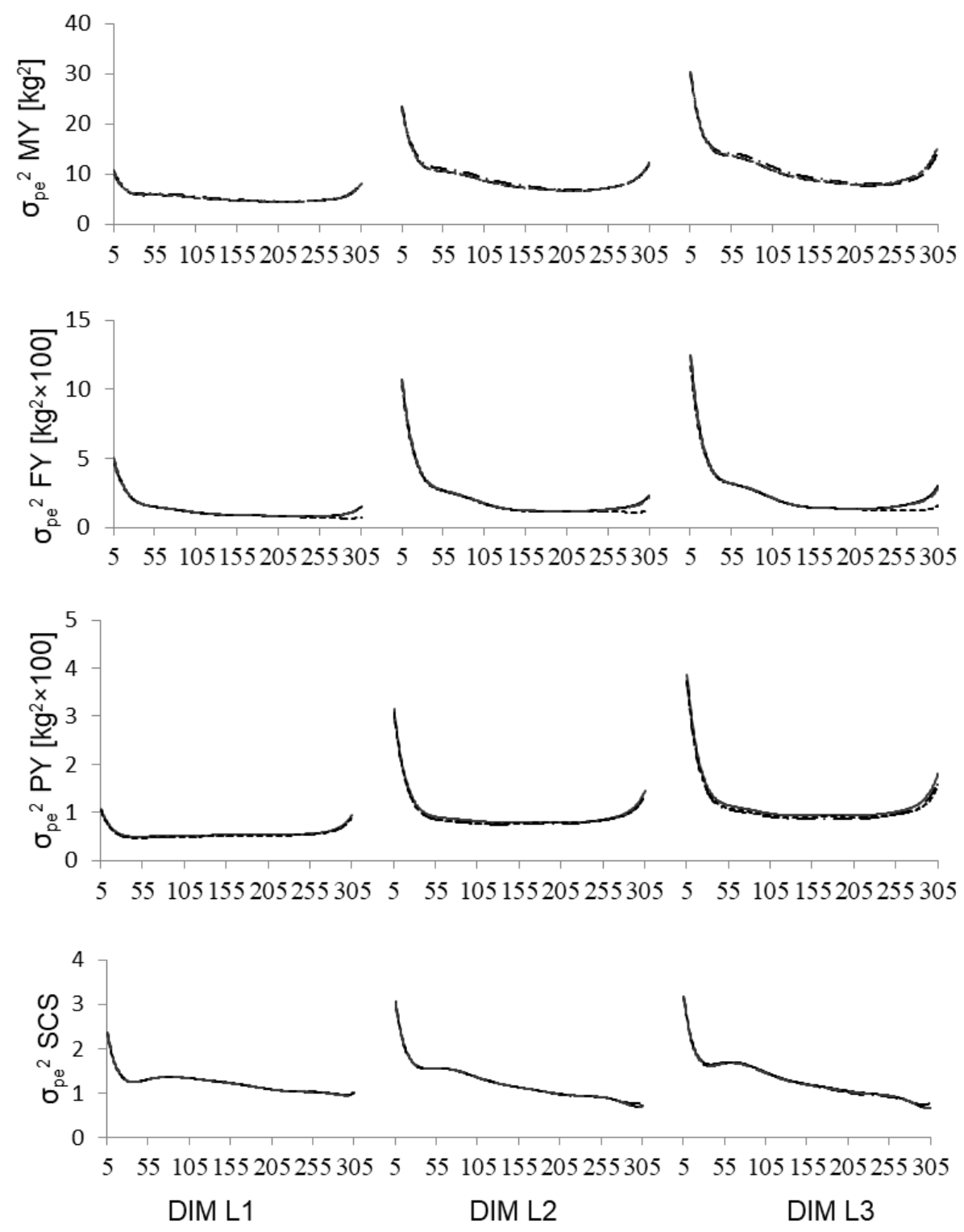
Table 2. Heritability (diagonal), genetic correlation (below diagonal) and environmental correlation (above diagonal) for whole lactation yields, and somatic cell score (SCS) based on results of a test-day random regression model.

\begin{tabular}{lcccccccccccc}
\hline & $\mathbf{M Y}_{1}$ & $\mathbf{M Y}_{2}$ & $\mathbf{M Y}_{3}$ & $\mathbf{F Y}_{1}$ & $\mathbf{F Y}_{2}$ & $\mathbf{F Y}_{3}$ & $\mathbf{P Y}_{1}$ & $\mathbf{P Y}_{2}$ & $\mathbf{P Y}_{3}$ & $\mathbf{S C S}_{1}$ & $\mathbf{S C S}_{2}$ & $\mathbf{S C S}_{3}$ \\
\hline $\mathbf{M Y}_{1}$ & $\mathbf{0 . 4 3}$ & 0.40 & 0.30 & 0.89 & 0.36 & 0.25 & 0.98 & 0.44 & 0.32 & -0.19 & 0.01 & 0.05 \\
$\mathbf{M Y}_{2}$ & 0.93 & $\mathbf{0 . 3 4}$ & 0.43 & 0.32 & 0.87 & 0.36 & 0.41 & 0.97 & 0.46 & -0.04 & -0.16 & 0.03 \\
$\mathbf{M Y}_{3}$ & 0.86 & 0.94 & $\mathbf{0 . 3 3}$ & 0.22 & 0.36 & 0.87 & 0.31 & 0.46 & 0.98 & -0.02 & -0.02 & -0.17 \\
& & & & & & & & & & & & \\
$\mathbf{F Y}_{1}$ & 0.83 & 0.75 & 0.75 & $\mathbf{0 . 3 9}$ & 0.39 & 0.28 & 0.87 & 0.81 & 0.77 & -0.20 & 0.00 & 0.03 \\
$\mathbf{F Y}_{2}$ & 0.68 & 0.74 & 0.74 & 0.92 & $\mathbf{0 . 3 2}$ & 0.44 & 0.76 & 0.82 & 0.81 & -0.03 & -0.18 & 0.02 \\
$\mathbf{F Y}_{3}$ & 0.65 & 0.66 & 0.75 & 0.88 & 0.92 & $\mathbf{0 . 3 6}$ & 0.74 & 0.77 & 0.85 & -0.03 & -0.03 & -0.18 \\
& & & & & & & & & & & & \\
$\mathbf{P Y}_{1}$ & 0.92 & 0.84 & 0.79 & 0.88 & 0.36 & 0.24 & $\mathbf{0 . 4 1}$ & 0.44 & 0.30 & -0.18 & 0.03 & 0.06 \\
$\mathbf{P Y}_{2}$ & 0.83 & 0.89 & 0.84 & 0.36 & 0.86 & 0.38 & 0.94 & $\mathbf{0 . 3 5}$ & 0.48 & -0.05 & -0.15 & 0.04 \\
$\mathbf{P Y}_{3}$ & 0.76 & 0.82 & 0.89 & 0.24 & 0.38 & 0.86 & 0.87 & 0.95 & $\mathbf{0 . 3 6}$ & -0.01 & -0.03 & -0.15 \\
$\mathbf{S C S}_{1}$ & 0.06 & 0.00 & 0.01 & 0.05 & -0.06 & 0.01 & 0.05 & -0.02 & 0.00 & $\mathbf{0 . 2 3}$ & 0.36 & 0.21 \\
$\mathbf{S C S}_{2}$ & 0.03 & -0.09 & -0.08 & -0.01 & -0.17 & -0.07 & 0.02 & -0.10 & -0.07 & 0.87 & $\mathbf{0 . 2 3}$ & 0.41 \\
$\mathbf{S C S}_{3}$ & 0.07 & -0.07 & -0.10 & -0.02 & -0.20 & -0.14 & 0.03 & -0.11 & -0.11 & 0.70 & 0.85 & $\mathbf{0 . 2 1}$ \\
\hline
\end{tabular}

$\mathrm{MY}_{\mathrm{n}}$ : Milk yield in the $\mathrm{n}^{\text {th }}$ lactation, $F Y_{\mathrm{n}}$ : Fat yield in the $\mathrm{n}^{\text {th }}$ lactation, $\mathrm{PY}_{\mathrm{n}}$ : Protein yield in the $\mathrm{n}^{\text {th }}$ lactation, $\operatorname{SCS}_{\mathrm{n}}$ : Somatic cell score in the $\mathrm{n}^{\text {th }}$ lactation

Table 3. Heritability (diagonal), genetic correlation (below diagonal) and environmental correlation (above diagonal) for whole lactation yields, and somatic cell score (SCS) in first three lactations based on a lactation model.

\begin{tabular}{lcccccccccccc}
\hline & $\mathbf{M Y}_{1}$ & $\mathbf{M Y}_{2}$ & $\mathbf{M Y}_{\mathbf{3}}$ & $\mathbf{F Y}_{1}$ & $\mathbf{F Y}_{2}$ & $\mathbf{F Y}_{\mathbf{3}}$ & $\mathbf{P Y}_{1}$ & $\mathbf{P Y}_{2}$ & $\mathbf{P Y}_{3}$ & $\mathbf{S C S}_{\mathbf{1}}$ & $\mathbf{S C S}_{\mathbf{2}}$ & $\mathbf{S C S}_{\mathbf{3}}$ \\
\hline $\mathbf{M Y}_{1}$ & $\mathbf{0 . 4 1}$ & 0.36 & 0.26 & 0.84 & 0.31 & 0.24 & 0.97 & 0.39 & 0.27 & -0.18 & 0.00 & 0.04 \\
$\mathbf{M Y}_{2}$ & 0.96 & $\mathbf{0 . 3 2}$ & 0.40 & 0.28 & 0.81 & 0.32 & 0.35 & 0.96 & 0.41 & -0.04 & -0.18 & 0.00 \\
$\mathbf{M Y}_{3}$ & 0.91 & 0.97 & $\mathbf{0 . 3 1}$ & 0.20 & 0.32 & 0.84 & 0.26 & 0.41 & 0.97 & -0.03 & -0.03 & -0.18 \\
& & & & & & & & & & & & \\
$\mathbf{F Y}_{1}$ & 0.83 & 0.80 & 0.76 & $\mathbf{0 . 3 2}$ & 0.34 & 0.23 & 0.89 & 0.88 & 0.81 & -0.16 & -0.02 & 0.01 \\
$\mathbf{F Y}_{2}$ & 0.75 & 0.78 & 0.77 & 0.95 & $\mathbf{0 . 2 6}$ & 0.36 & 0.82 & 0.90 & 0.85 & -0.05 & -0.18 & -0.03 \\
$\mathbf{F Y}_{3}$ & 0.62 & 0.67 & 0.68 & 0.90 & 0.96 & $\mathbf{0 . 3 0}$ & 0.66 & 0.75 & 0.75 & -0.03 & -0.03 & -0.17 \\
& & & & & & & & & & & & \\
$\mathbf{P Y}_{1}$ & 0.92 & 0.88 & 0.82 & 0.82 & 0.31 & 0.24 & $\mathbf{0 . 3 9}$ & 0.40 & 0.28 & -0.16 & 0.01 & 0.04 \\
$\mathbf{P Y}_{2}$ & 0.87 & 0.88 & 0.85 & 0.31 & 0.79 & 0.34 & 0.96 & $\mathbf{0 . 3 2}$ & 0.44 & -0.05 & -0.16 & 0.00 \\
$\mathbf{P Y}_{3}$ & 0.81 & 0.85 & 0.87 & 0.22 & 0.33 & 0.83 & 0.90 & 0.95 & $\mathbf{0 . 3 2}$ & -0.02 & -0.03 & -0.15 \\
$\mathbf{S C S}_{1}$ & 0.08 & 0.08 & 0.07 & 0.07 & 0.04 & 0.04 & 0.08 & 0.05 & 0.05 & $\mathbf{0 . 1 6}$ & 0.39 & 0.26 \\
$\mathbf{S C S}_{2}$ & 0.07 & 0.04 & 0.03 & 0.05 & 0.01 & 0.00 & 0.07 & 0.03 & 0.02 & 0.52 & $\mathbf{0 . 1 5}$ & 0.45 \\
$\mathbf{S C S}_{3}$ & 0.07 & 0.04 & 0.03 & 0.05 & 0.02 & 0.01 & 0.05 & 0.03 & 0.02 & 0.29 & 0.35 & $\mathbf{0 . 1 5}$ \\
\hline
\end{tabular}

$\mathrm{MY}_{\mathrm{n}}$ : Milk yield in the $\mathrm{n}^{\text {th }}$ lactation, $F Y_{\mathrm{n}}$ : Fat yield in the $\mathrm{n}^{\text {th }}$ lactation, $\mathrm{PY}_{\mathrm{n}}$ : Protein yield in the $\mathrm{n}^{\text {th }}$ lactation, $\mathrm{SCS}_{\mathrm{n}}$ : Somatic cell score in the $\mathrm{n}^{\text {th }}$ lactation. 
lactations was 0.32 to 0.36 for these traits. SCS heritability was 0.23 in the first two lactations and 0.21 in the third lactation. The genetic correlation between different lactations was 0.86-0.95 for the yield traits but lower for SCS. The genetic correlation between MY and PY in the same lactation was $0.89-0.92$, between MY and FY it was 0.74-0.83, and between FY and PY the correlation was $0.82-0.87$. The genetic correlation between SCS and yield traits was low and negative in later lactations. The environmental correlation between lactation SCS and yield traits in the same lactation was negative and ranged from -0.15 to -0.20 , but was low between SCS and yield in other lactations.

Lactation heritability was lower for all traits based on the lactation model (Table 3) than based on the RR model. The negative genetic correlation between yield traits and SCS in the second and third lactations was not evident in the estimates from the lactation model.

The results on persistency of lactation are presented in Table 5. The linear term of the LP had heritability from 0.13 for the SCS for the first lactation to 0.24 for the MY of the first lactation. This measure of persistency had a low positive genetic correlation to whole lactation yields for all traits in all lactations. The persistency of the yield traits had a low negative genetic correlation with the lactation SCS for the same lactation.

\section{DISCUSSION}

\section{Variance components}

Having three estimates of variance components within traits with relatively small differences

Table 4. Correlations between days in milk (DIM) within each trait, genetic correlations below diagonal within each block and environmental correlation in italics above diagonals in each block.

\begin{tabular}{|c|c|c|c|c|c|c|c|c|c|c|c|c|c|}
\hline \multirow{2}{*}{ DIM } & & \multicolumn{4}{|c|}{ First lactation } & \multicolumn{4}{|c|}{ Second lactation } & \multicolumn{4}{|c|}{ Third lactation } \\
\hline & & 10 & 100 & 200 & 300 & 10 & 100 & 200 & 300 & 10 & 100 & 200 & 300 \\
\hline \multirow{6}{*}{$\sum$} & 10 & 1 & 0.45 & 0.36 & 0.19 & 1 & 0.40 & 0.29 & 0.12 & 1 & 0.33 & 0.27 & 0.10 \\
\hline & 100 & 0.81 & 1 & 0.73 & 0.43 & 0.60 & 1 & 0.69 & 0.39 & 0.48 & 1 & 0.68 & 0.30 \\
\hline & 200 & 0.68 & 0.94 & 1 & 0.58 & 0.41 & 0.91 & 1 & 0.55 & 0.41 & 0.89 & 1 & 0.55 \\
\hline & 300 & 0.46 & 0.75 & 0.84 & 1 & 0.17 & 0.6 & 0.77 & 1 & 0.13 & 0.57 & 0.68 & 1 \\
\hline & 10 & 1 & 0.27 & 0.27 & 0.17 & 1 & 0.22 & 0.20 & 0.09 & 1 & 0.16 & 0.22 & 0.12 \\
\hline & 100 & 0.70 & 1 & 0.51 & 0.33 & 0.51 & 1 & 0.45 & 0.28 & 0.55 & 1 & 0.45 & 0.25 \\
\hline \multirow[b]{2}{*}{$\bar{I}$} & 200 & 0.58 & 0.93 & 1 & 0.47 & 0.33 & 0.91 & 1 & 0.41 & 0.39 & 0.88 & 1 & 0.44 \\
\hline & 300 & 0.40 & 0.78 & 0.87 & 1 & 0.06 & 0.63 & 0.8 & 1 & 0.12 & 0.64 & 0.73 & 1 \\
\hline \multirow{6}{*}{ ¿ } & 10 & 1 & 0.40 & 0.34 & 0.19 & 1 & 0.40 & 0.33 & 0.18 & 1 & 0.32 & 0.31 & 0.17 \\
\hline & 100 & 0.79 & 1 & 0.70 & 0.44 & 0.72 & 1 & 0.66 & 0.42 & 0.63 & 1 & 0.66 & 0.37 \\
\hline & 200 & 0.67 & 0.94 & 1 & 0.59 & 0.58 & 0.92 & 1 & 0.56 & 0.54 & 0.91 & 1 & 0.58 \\
\hline & 300 & 0.46 & 0.79 & 0.87 & 1 & 0.35 & 0.69 & 0.81 & 1 & 0.28 & 0.64 & 0.72 & 1 \\
\hline & 10 & 1 & 0.27 & 0.24 & 0.17 & 1 & 0.28 & 0.26 & 0.18 & 1 & 0.22 & 0.24 & 0.17 \\
\hline & 100 & 0.56 & 1 & 0.56 & 0.41 & 0.62 & 1 & 0.56 & 0.40 & 0.40 & 1 & 0.51 & 0.35 \\
\hline \multirow{2}{*}{ U્ } & 200 & 0.45 & 0.89 & 1 & 0.56 & 0.55 & 0.90 & 1 & 0.52 & 0.41 & 0.82 & 1 & 0.49 \\
\hline & 300 & 0.34 & 0.84 & 0.89 & 1 & 0.36 & 0.73 & 0.73 & 1 & 0.33 & 0.68 & 0.68 & 1 \\
\hline
\end{tabular}

DIM: Days in milk, MY: milk yield, FY: fat yield, PY: protein yield, SCS: somatic cell score 
Table 5. Heritability of the coefficient for second Legendre polynomial $\left(\mathrm{h}^{2}\right)$, genetic correlation to lactation yields $\left(\mathrm{r}_{\mathrm{lac}}\right)$ and genetic correlation to lactation somatic cell score $\left(\mathrm{r}_{\mathrm{SCS}}\right)$.

\begin{tabular}{lcrrr}
\hline & Lactation & $\mathbf{h}^{2}$ & $\mathbf{r}_{\text {lac }}$ & $\mathbf{r}_{\text {SCS }}$ \\
\hline Milk yield & 1 & 0.24 & 0.07 & -0.12 \\
& 2 & 0.20 & 0.13 & -0.08 \\
& 3 & 0.23 & 0.15 & -0.09 \\
Fat yield & 1 & 0.19 & 0.05 & -0.10 \\
& 2 & 0.14 & 0.12 & -0.07 \\
& 3 & 0.18 & 0.11 & -0.08 \\
Protein & 1 & 0.22 & 0.09 & -0.12 \\
yield & 2 & 0.15 & 0.12 & -0.09 \\
& 3 & 0.21 & 0.14 & -0.06 \\
Somatic & & & & \\
cell score & 2 & 0.15 & 0.06 & \\
& 3 & 0.18 & 0.10 & \\
\hline
\end{tabular}

strengthens our confidence in the results from this part of the study, although all estimates were based on the same data. More fluctuation of results for later lactations was expected due to fewer records, which therefore resulted in less accurate estimates. The lower PE variance of FY in late lactation when estimated with SCS compared to when estimated with MY or PY resulted in a pattern more similar to SCS than the yield traits (Figure 2).

Earlier studies have reported higher genetic and PE variance towards the end of lactation (e.g. Strabel \& Jamrozik 2006, Hammami et al. 2008). Nonetheless, the peak for PE variance of, for example, FY in the third lactation was higher than is plausible. Some more complete RR models account for heterogeneous residual variance in different parts of the lactation (e.g. Druet et al. 2005, Lidauer et al. 2015). This study and other studies (Strabel \& Jamrozik 2006, Hammami et al. 2008) reporting a similar variance pattern do assume homogeneous residual variance throughout the lactation.
Because of the more difficult computing and the fact that model testing did not indicate a better fit for models accounting for heterogeneous residual variance, this was not included in the model. However, results indicated higher residual variance at the beginning of the lactation, which is in agreement with the results of Druet et al. (2005). The PE and genetic variance functions may have absorbed this higher residual variance in the beginning, contributing to this high variance peak. Other concerns were whether the average phenotypic curves were based on too small groups to give a good fit and whether fitting LP for the fixed curve fit sufficiently in early lactation when the yield was increasing rapidly. The minimum number of records in the herd-year groups, which the fixed lactation curves were estimated for, was set to 30 . Greater minimum group size was not considered desirable since that would result in groups covering many years in the smaller herds. Fitting an exponential term, such as the Wilmink function for the fixed curve, could also have fitted better and thus resulted in less residual variance at the beginning of lactation.

\section{Heritability and correlations}

Heritability of daily yields has not been reported for Icelandic dairy cows before. The results fall within the range of results for other breeds. The highest heritability estimates for first lactation daily MY in the literature are either higher than ours, for example Druet et al. (2005), lower than ours, for example Hammami et al. (2008), or similar (Jakobsen et al. 2002). Heritability of daily SCS (Figure 3) obtained here was higher than results from studies of other breeds, as found by Koivula et al. (2004) or similar to the results of Druet et al. (2005) and Elsaid et al. (2011). The highest heritability in late lactation was also in agreement with studies of other breeds, (e.g. Druet et al. 2005, Elsaid et al. 2011).

Heritability estimates for lactation yields from both models were higher than previous estimates for Icelandic cows (Jonmundsson 1980, Sigurdsson 1993, Sigurdsson \& Jonmundsson 2011). Lactation yields in their 
studies were not calculated in the same manner as the lactation yields presented here, so the difference in heritability could be because of model difference. Heritability estimates are known to be dependent on the environment in which the animals are recorded (Falconer 1989). The production level of Icelandic cows has been rising in recent decades and the higher production level with better feeding and environment may have allowed the cows to show more of their genetic potential, resulting in higher heritability estimates. Hammami et al. (2008) explained low heritability of MY in Tunisian Holsteins with their low production level. Another possible explanation is that recording has become more regular and better milking equipment should

Figure 3. Heritability of daily milk yield (MY), fat yield (FY), protein yield (PY), and somatic cell score (SCS) on days in milk (DIM) 5-305 in lactations 1(L1), lactation 2(L2) and lactation 3(L3), estimated with MY (whole line), FY (broken line), PY (dot-line-dot) and SCS (dots) as a correlated trait.
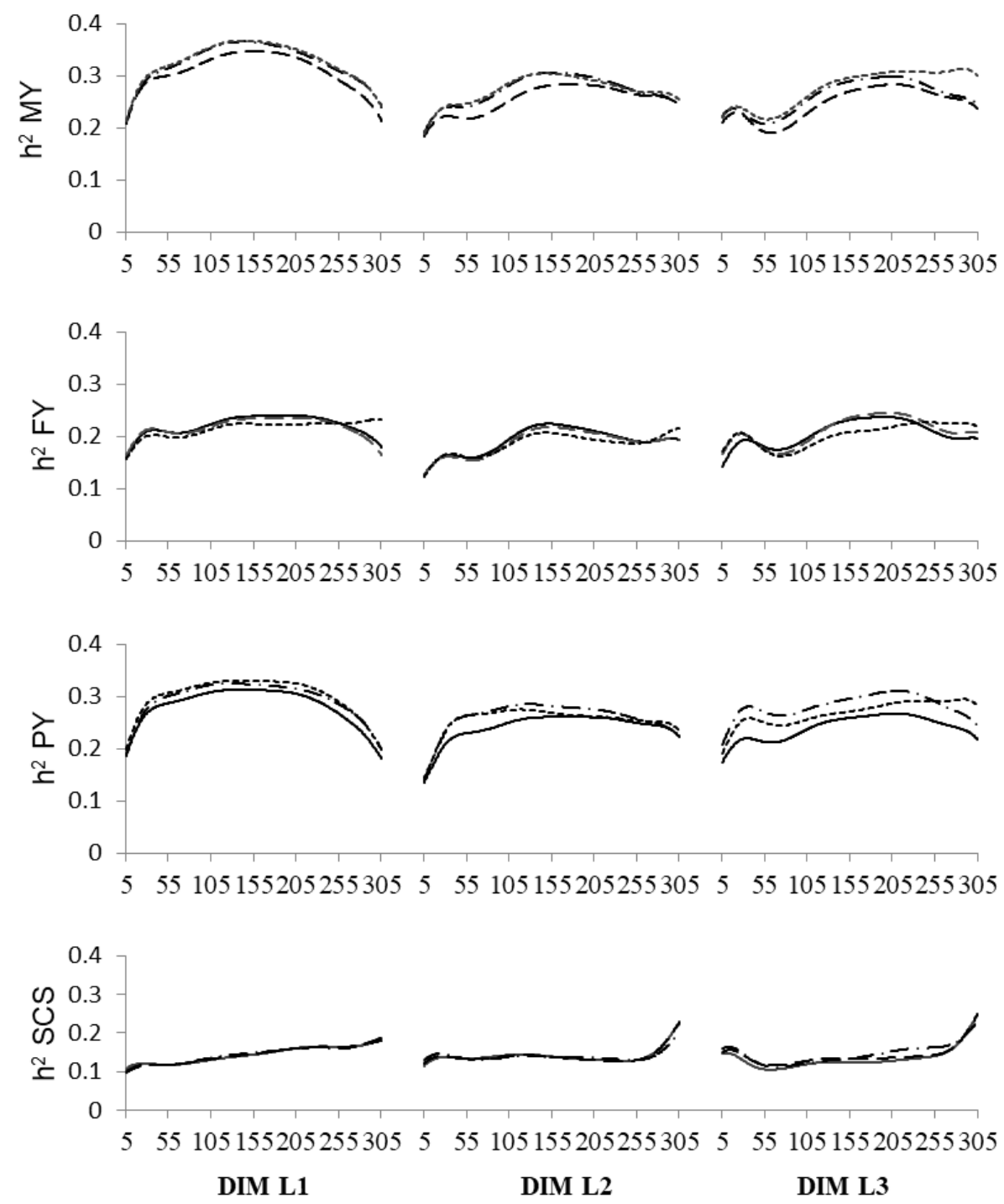
allow for more precise weighing and sample collection for component estimation, resulting in more accurate records. Values of lactation FY and PY were based on a larger number of milk samples per lactation in the data used in this study than was common for previous studies. The fact that the majority of the data used for estimation was from the last years of the study period has possibly increased the effects of improved environment or recording from what could be expected if the data had been more evenly spread over the study period.

The RR model accounts for herd-test-day effects and is thus expected to yield higher heritability estimates than a lactation model, as was the case in this study. The herd-test-day variance explained the highest proportion of the total variance for FY in all lactations, which could explain the difference in heritability between the two models for FY. However, the herd-test-day variance explained only 3 to $5 \%$ of the SCS variance, though in contrast heritability was estimated to be $0.06-0.08$ higher using the TD model. Heritability of SCS using the RR model was higher than previously estimated for the breed (Jónsson et al. 1994, Sigurðsson 1997). The RR model did not include test-month effect. Including one could improve the model and account for part of the variability estimated as herd-test-day variance here.

Genetic correlations between TD yields within lactations (Table 4) were within expectations for most of the traits and in line with results for other breeds (e.g. Kettunen 2000). Results on phenotypic correlations between TD yields in the first lactation showed the same pattern for the Icelandic cow (Jónmundsson 1980). Genetic correlations between first and later lactations obtained here (Tables 2 and 3) were higher than Sigurdsson (1993) estimated for the breed. The low positive correlation between SCS and MY in the first lactation but negative in later lactations (Table 2) is in agreement with Haile-Mariam et al. (2001). This suggests that emphasis on selection for yields in later lactations rather than first is more beneficial for udder health. However, these correlations were low and were not observed for the lactation model. De los Campos et al. (2006) found negative correlations between SCS and yield on TD basis to be originated from the negative effect of infection, which leads to increased SCS and decreased yields.

\section{Persistency}

Considerable genetic variation for the linear LP term was observed in the population (Table 5), suggesting that it is possible to change the shape of the lactation curve for the population and increase persistency of lactation. The correlation between SCS and the persistency measure suggests that increased persistency could be beneficial for udder health. Haile-Mariam et al. (2003) and Strapáková et al. (2016) also found this correlation to be evident but low. However, more research is needed on other aspects of selection for the shape of the lactation curve, on definition of the trait (see e.g. Jakobsen et al. 2002) and what effect the current selection on yield has on the shape of the lactation curve. Negative genetic correlation between yield traits and SCS later in lactation is in agreement with persistency being correlated to lower yield.

Information on the stage of gestation was not available for this study. Consequently, days in gestation on a TD could not be included in the model. Including information about the day of gestation is likely to improve the model for later parts of the lactation (Haile-Mariam et al. 2003). This could also reduce the risk that the production trait model favours cows with low genetic merit for fertility.

\section{CONCLUSIONS}

An RR model for genetic evaluation of yield traits and SCS could better account for environmental effects than a lactation model, giving higher heritability estimates of these traits. Implementing an RR model is thus likely to be beneficial for the genetic evaluation of the population studied, especially when combined with other benefits of the RR model. The model presented here showed some unrealistic estimates in the beginning of lactation and could probably be improved by accounting for heterogeneous residual variance and by using 
other covariates for the fixed regression curve. A better production environment, along with more regular and better recording, have resulted in higher heritability of yield traits and SCS in the population than estimates with older data have shown. Genetic variation in the shape of the lactation curve was evident in the population. The curve can thus be modified with selection, e.g. by selecting for more persistent lactation. Whether this is desirable and how it could best be done requires further investigation.

\section{ACKNOWLEDGEMENT}

Financial support from the Icelandic Cattle Productivity Fond is acknowledged.

\section{REFERENCES}

Adalsteinsson S 1981. Origin and conservation of farm animal populations in Iceland. Journal of Animal Breeding and Genetics 98, 258-264.

De los Campos G, Gianola D \& Heringstad B 2006. A structural equation model for describing relationships between somatic cell score and milk yield in first-lactation dairy cows. Journal of Dairy Science 89, 4445-4455.

https://doi.org/10.3168/jds.S0022-0302(06)72493-6

Druet T, Jaffrézic F, Boichard D \& Ducrocq V 2003. Modeling lactation curves and estimation of genetic parameters for first lactation test-day records of French Holstein cows. Journal of Dairy Science 86, 2480-2490.

https://doi.org/10.3168/jds.S0022-0302(03)73842-9

Druet T, Jaffrézic F \& Ducrocq V 2005. Estimation of genetic parameters for test day records of dairy traits in the first three lactations. Genetics Selection Evolution 37, 1-16.

https://doi.org/10.1186/1297-9686-37-4-257

Dzomba EF, Nephawe KA, Maiwashe AN, Cloete SWP, Chimonyo M, Banga CB, Muller CJC \& Dzama K 2010. Random regression test-day model for the analysis of dairy cattle production data in South Africa: Creating the framework. South African Journal of Animal Science 40, 273284.

https://oi.org/10.4314/sajas.v40i4.65235

Elsaid R, Sabry A, Lund MS \& Madsen P 2011. Genetic analysis of somatic cell score in Danish dairy cattle using random regression test-day model. Livestock Science 140, 95-102.

https://doi.org/10.1016/j.livsci.2011.02.013

Falconer DS 1989. Introduction to Quantitative Genetics. 3rd ed. Harlow: Longman. 438 p.

Hagstofa Íslands 2017. Búpeningur eftir landsvaeðum frá 1980 [Livestock numbers since 1980]. Accessed 1.4.2017 from http://px.hagstofa.is/ pxispxis/pxweb/is/Atvinnuvegir/Atvinnuvegir landbunadur_landbufe/LAN10102.px/ $\overline{[\mathrm{In}}$ Icelandic]

Haile-Mariam M, Bowman PJ \& Goddard ME 2001. Genetic and environmental correlations between test-day somatic cell count and milk yield traits. Livestock Production Science 73, 1-13.

https://doi.org/10.1016/S0301-6226(01)00232-9

Haile-Mariam M, Bowman PJ \& Goddard ME 2003. Genetic and environmental relationship among calving interval, survival, persistency of milk yield and somatic cell count in dairy cattle. Livestock Production Science 80, 189-200. https://doi.org/10.1016/S0301-6226(02)00188-4

Hammami H, Rekik B, Soyeurt H, Ben Gara A \& Gengler N 2008. Genetic parameters for Tunisian Holsteins using a test-day tandom regression model. Journal of Dairy Science 91, 2118-2126. https://doi.org/10.3168/jds.2007-0382

Jakobsen JH, Madsen P, Jensen J, Pedersen J, Christensen LG \& Sorensen DA 2002. Genetic parameters for milk production and persistency for Danish Holsteins estimated in random regression models using REML. Journal of Dairy Science 85, 1607-1616.

https://doi.org/10.3168/jds.S0022-0302(02)74231-8

Jamrozik J, Schaeffer LR \& Weigel KA 2002. Genetic evaluation of bulls and cows with singleand multiple-country test-day models. Journal of Dairy Science 85 1617-1622.

https://doi.org/10.3168/jds.S0022-0302(02)74232-X

Jónmundsson JV, Stefánsson ÓE \& Jóhannsson E 1977. Rannsókn á afurðatölum úr skýrslum nautgriparæktarfélaganna II. Arfgengi mjólkurframleiðslueiginleika og fylgni milli peirra [A study on yield records from the Cattle Breeding Societies II. Heritability of production traits and correlations between them]. Íslenskar landbúnaðarrannsóknir 9, 76-91. [In Icelandic]

Jónmundsson JV 1980. Rannsókn á afurðatölum fyrir fyrstakálfskvígur [A study on yields of first 
parity cows]. Íslenskar landbúnaðarrannsóknir 12, 61-83. [In Icelandic]

Jónsson E, Oddgeirsson Ó \& Jónmundsson JV 1994. Pættir sem hafa áhrif á frumutölu í mjólk íslenskra kúa [Factors affecting somatic cell count in Icelandic dairy cows]. Búvísindi 8, 27-40. [In Icelandic]

Kettunen A, Mäntysaari EA \& Pösö J 2000. Estimation of genetic parameters for daily milk yeld of primiparous Ayrshire cows by random regression test-day models. Livestock Production Science 66, 251-261.

https://doi.org/10.1016/S0301-6226(00)00166-4

Kirkpatrick M, Hill WG \& Thompson R 1994. Estimating the covariance structure of traits during growth and ageing, illustrated with lactation in dairy cattle. Genetical Research 64, 57-69.

Koivula M, Negussie E \& Mäntysaari EA 2004. Genetic parameters for test-day somatic cell count at different lactation stages of Finnish dairy cattle. Livestock Production Science 90, 145-157. https://doi.org/10.1016/j.livprodsci.2004.03.004

Lidauer MH, Pösö J, Pedersen J, Lassen J, Madsen P, Mäntysaari EA, Nielsen US, Eriksson J, Johansson K, Pitkänen T, Strandén I \& Aamand, GP 2015. Across-country test-day model evaluations for Holstein, Nordic Red Cattle, and Jersey. Journal of Dairy Science 98, 1296-1309. https://doi.org/10.3168/jds.2014-8307

Meyer K, \& Hill WG 1997. Estimation of genetic and phenotypic covariance functions for longitudinal or 'repeated' records by Restricted Maximum Likelihood. Livestock Production Science 47, 185-200.

https://doi.org/10.1016/S0301-6226(96)01414-5

Misztal I, Tsuruta S, Lourenco D, Masuda Y, Aguilar I, Legarra A \& Vitezica Z 2016. Manual for BLUPF90 Family of Programs. Athens, USA: University of Georgia. Accessed 15.11.2016 from http://nce.ads.uga.edu/wiki/lib/exe/fetch. php?media=blupf90_all2.pdf

Schaeffer LR, \& Dekkers JCM 1994. Random regressions in animal models for test-day production in dairy cattle. In: Proceedings of the 5th World Congress of Genetics Applied to Livestock Production. Guelph: University of Guelph, Vol. 18, 443-446.
Schaeffer LR, Jamrozik J, Kistemaker GJ \& Van Doormaal J 2000. Experience with a test-day model. Journal of Dairy Science, 83, 1135-1144. https://doi.org/10.3168/jds.S0022-0302(00)74979-4

Sigurdsson A 1993. Estimation of genetic and phenotypic parameters for production traits of Icelandic dairy cattle. Acta Agriculturae Scandinavica Section A, Animal science 43, 81-86.

Sigurdsson A 1997. Kynbótamat fyrir frumutölu [Estimated breeding values for somatic cell count]. Nautgriparcektin 14, 9-17. [In Icelandic]

Sigurdsson A \& Jonmundsson JV 2011. Genetic potential of Icelandic dairy cattle. Icelandic Agricultural Sciences 24, 55-64.

Strabel T \& Jamrozik J 2006. Genetic analysis of milk production traits of Polish black and white cattle using large-scale random regression test-day models. Journal of Dairy Science 89, 3152-3163. https://doi.org/10.3168/jds.S0022-0302(06)72589-9

Strapáková E, Candrák J \& Strapák P 2016. Genetic relationship of lactation persistency with milk yield, somatic cell score, reproductive traits, and longevity in Slovak Holstein cattle. Archives Animal Breeding 59, 329-335. https://doi.org/10.5194/aab-59-329-2016

Van der Werf JHJ, Goddard ME \& Meyer $K$ 1998. The use of covariance functions and random regressions for genetic evaluation of milk production based on test day records. Journal of Dairy Science 81, 3300-3308.

https://doi.org/10.3168/jds.S0022-0302(98)75895-3

Manuscript received 11 November 2018 Accepted 21 February 2019 